\title{
Edukacja w zakresie marketingu a jego wizerunek w Polsce
}

\section{MARKETING EDUCATION AND IMAGE OF MARKETING IN POLAND}

\begin{abstract}
Edukacja akademicka $w$ zakresie marketingu oraz powszechna edukacja ekonomiczna społeczeństwa maja wplyw na kształtowanie wizerunku marketingu $w$ Polsce. Artykut przedstawia porównanie badań dotyczacych opinii na temat marketingu przeprowadzonych $w$ roku 2007 i 2014. Dodatkowo wtaczono analize wykorzystujaca tzw. Indeks Zaufania do Marketingu. Ukazano zakres $i$ kierunki zmian „świadomości marketingowej”. Ogólnie rzecz biorac, po okresie dużego krytycyzmu wobec marketingu, obecnie powoli nastęuje proces pozytywnej zmiany w opiniach.
\end{abstract}

Slowa kluczowe: wizerunek marketingu, edukacja ekonomiczna w Polsce

\section{Wprowadzenie}

Historia edukacji w zakresie marketingu pokrywa się $\mathrm{w}$ zasadzie $\mathrm{z}$ historia samego marketingu jako dyscypliny zainteresowania w Polsce i sięga lat 70. ubiegłego wieku. W tym czasie pojawiły się pierwsze wykłady na ten temat na polskich uczelniach, ukazały pierwsze podręczniki, rozpoczęto dyskusje na konferencjach naukowych. W ciągu kolejnych blisko 50 lat, marketing przeżywał wzrost i spadek zainteresowania, ale w tym czasie ewoluowały także jego szczegółowe koncepcje. Koncepcje te oraz praktyczne działania spowodowały wykształcanie się różnych postaw wobec marketingu i przyczyniły się do ukształtowania zróżnicowanego wizerunku. Wśród nich można odnaleźć koncepcje, które można by określić jako pożądane, rzeczywiste i niechciane ${ }^{1}$. Wielu publikacjom, a także licznym dyskusjom na konferencjach naukowych towarzyszyła często obawa o „rozmywanie” tożsamości marketingu i obniżanie standardów merytorycznych i metodycznych podejść. Występujące niekiedy skupianie się na ,poboczach” marketingu, przemijających modach, atrakcyjnych jedynie werbalnie pojęciach wywoływało sprzeciw części środowiska badaczy problematyki marketingowej. Niektóre publikacje zostały w pewnym zakresie dostrzeżone; trudno jednak $\mathrm{z}$ całą stanowczością stwierdzić, że zostały w pełni zaakceptowane 1 uwzględnione w praktycznym działaniu.

\footnotetext{
${ }^{1}$ Garbarski L., Pożądane, rzeczywiste i niechciane oblicza marketingu. W: Marketing - aktualne problemy i kierunki ewolucji. Pod redakcją M. Gębarowskiego, L. Witek, B. Zatwarnickiej-Madury. Oficyna Wydawnicza Politechniki Rzeszowskiej. Rzeszów 2012, s. 91-99.
} 
W latach $70 \mathrm{XX}$ wieku podstawowe zagadnienia marketingowe były przedstawiane w wykładach i ćwiczeniach odbywających się często pod innym tytułem. Autorzy pojawiających się wtedy pierwszych w Polsce podręczników marketingu byli często zmuszeni do poszukiwania różnych odpowiedników tej nazwy, aby podręczniki te mogły się w ogóle ukazać. Dla studentów w tamtych czasach „marketing” stał się koncepcją bardzo atrakcyjną, do studiowania której nie trzeba było nikogo zmuszać. Co więcej, wydawał się koncepcją logiczną, pożądaną, choć dość trudną do praktycznego wykorzystania w ówczesnej polskiej rzeczywistości gospodarczej. W latach 80 edukacyjna aktywność nadal była na stosunkowo dużym poziomie, natomiast praktyczne zastosowania mogły ograniczać się jedynie do działań na rynkach zagranicznych. Zmiany polityczne i gospodarcze w latach $90 \mathrm{z}$ całą mocą wzmogły zainteresowanie marketingiem. Z punktu widzenia edukacyjnego zasadnicza zmiana dokonała się w kierunkach studiów. Dawne kierunki, nie przystające do nowej rzeczywistości zaczęły ulegać przekształceniom, a wyrósł dość powszechnie kierunek „Zarządzanie i Marketing". Wprawdzie nazwa ta była pewnym uproszczeniem i niedokładnością, jednak uruchamianie tego kierunku studiów stało się dość powszechne.

W pierwszej dekadzie XXI wieku nastapiło najpierw spowolnienie tempa akceptacji marketingu, a później wręcz odwrócenie trendu zainteresowania i narastanie coraz ostrzejszego krytycyzmu wobec niego. W mediach coraz częściej podawano liczne przykłady wątpliwych, wręcz manipulatorskich działań firm. Szeroko rozpowszechniony kierunek studiów z lat 90. „Zarządzanie i Marketing” został pozbawiony swojego drugiego członu i pozostał jako „Zarządzanie”. I wreszcie lata 10. XXI wieku przyniosły powtórny wzrost zainteresowania marketingiem, ale w różnych jego wymiarach i w coraz większej złożoności procesów konkurencyjnych.

$\mathrm{Na}$ tle powyższych procesów powstają istotne pytania o kondycję marketingu jako przedmiotu studiów oraz jego dalsze perspektywy. Celem opracowania jest udzielenie odpowiedzi na dwa pytania:

1) Jak zmienia się wizerunek marketingu w Polsce w wyniku wieloletniej edukacji akademickiej i społecznej?

2) Jaka jest zależność pomiędzy opiniami na temat marketingu, a indeksem zaufania do marketingu?

\section{Analiza wizerunku marketingu}

Dobrym punktem wyjścia dla analizy wizerunku marketingu w Polsce są wyniki badań przeprowadzonych w latach 2005-2008 przez Katedrę Marketingu Uniwersytetu Ekonomicznego w Krakowie. Wyniki tych badań zostały opublikowane w książce „Wizerunek marketingu w Polsce (pod redakcją Romana Niestroja)” wydanej przez Wydawnictwo Uniwersytetu Ekonomicznego w Krakowie w 2009 roku. Badania te rozpoczęte sondażem w 2005 roku, były kontynuowane w latach 2007-2008 i objęły cztery oddzielne badania zmierzające do rozpoznania opinii studentów, nauczycieli akademickich, przedstawicieli biznesu oraz społeczeństwa na temat marketingu jako 
przedmiotu nauczania, obiektu badań naukowych oraz obszaru aktywności zawodowej i działalności praktycznej².

Podstawą wspomnianych powyżej badań był kwestionariusz składający się z 30 pytań. Wśród nich były pytania dotyczące różnych aspektów wizerunku marketingu, cech osobowych oraz przygotowania zawodowego specjalistów ds. marketingu, a także form nauczania adekwatnych dla grupy przedmiotów marketingowych. Badania zostały przeprowadzone w grudniu 2007 roku przez agencję badań rynkowych wśród użytkowników Internetu. Ostatecznie zakwalifikowano do analizy odpowiedzi 1909 respondentów, którzy w tym czasie studiowali lub w ciagu ostatnich pięciu lat ukończyli studia licencjackie, inżynierskie, magisterskie lub lekarskie. Jak już wcześniej wskazano, przeprowadzono także badania wśród innych grup respondentów, ale analiza ich wyników jest poza kręgiem zainteresowania niniejszego opracowania ${ }^{3}$.

Na potrzeby obecnego badania istotne są wyniki dotyczące tylko 10 pytań. One właśnie odzwierciedlały najpopularniejsze poglądy i obiegowe opinie na temat marketingu. Pytania miały formę stwierdzeń, zaś zadaniem respondentów było wyrażenie stopnia zgody z tymi stwierdzeniami na sześciostopniowej skali (5 punktów typowej skali Likerta oraz odpowiedź „trudno powiedzieć”). Zostały one przedstawione w tabeli nr 1 .

Tabela 1. Opinie studentów i absolwentów na temat marketingu (grudzień 2007) w badaniach zespołu R. Niestroja

\begin{tabular}{|l|c|c|c|c|c|c|}
\hline \multicolumn{1}{|c|}{$\begin{array}{c}\text { Opinie na temat } \\
\text { marketingu }\end{array}$} & $\begin{array}{c}\text { Zdecy- } \\
\text { dowani } \\
\text { e tak }\end{array}$ & $\begin{array}{c}\text { Raczej } \\
\text { tak }\end{array}$ & $\begin{array}{c}\text { Ani tak, } \\
\text { ani nie }\end{array}$ & $\begin{array}{c}\text { Raczej } \\
\text { nie }\end{array}$ & $\begin{array}{c}\text { Zdecy- } \\
\text { dowanie } \\
\text { nie }\end{array}$ & $\begin{array}{c}\text { Trudno } \\
\text { powie- } \\
\text { dzieć }\end{array}$ \\
\hline $\begin{array}{l}\text { Marketing to tak naprawdę to } \\
\text { samo, co reklama i promocja }\end{array}$ & 10,4 & 30,6 & 21,2 & 20,6 & 11,6 & 5,5 \\
\hline $\begin{array}{l}\text { Marketing to sztuka } \\
\text { manipulowania klientem }\end{array}$ & 34,7 & 37,6 & 12,9 & 7,7 & 2,7 & 4,5 \\
\hline $\begin{array}{l}\text { Marketing to coś } \\
\text { nieodzownego w biznesie }\end{array}$ & 51,4 & 30,8 & 7,3 & 3,5 & 3,3 & 3,8 \\
\hline $\begin{array}{l}\text { Marketing to interesująca } \\
\text { dziedzina dla kariery } \\
\text { zawodowej }\end{array}$ & 18,5 & 34,5 & 18,2 & 14,2 & 8,5 & 6,1 \\
\hline $\begin{array}{l}\text { Marketing to coś, co nie } \\
\text { potrzebnie podnosi ceny } \\
\text { produktów }\end{array}$ & 7,7 & 15,8 & 24,7 & 28,0 & 16,2 & 7,7 \\
\hline $\begin{array}{l}\text { Marketing to różne techniki } \\
\text { zwiększania sprzedaży }\end{array}$ & 49,5 & 39,4 & 5,4 & 1,9 & 0,6 & 3,3 \\
\hline $\begin{array}{l}\text { Marketing to coś, co skut- } \\
\text { kuje większymi możliwoś- } \\
\text { ciami wyboru dla klientów }\end{array}$ & 17,7 & 41,9 & 20,4 & 10,7 & 3,6 & 5,8 \\
\hline $\begin{array}{l}\text { Marketing to filozofia } \\
\text { działania firm uwzględnia- } \\
\text { jąca przede wszystkim } \\
\text { potrzeby klientów }\end{array}$ & 17,1 & 32,1 & 20,0 & 17,6 & 7,8 & 5,6 \\
\hline
\end{tabular}

2 Wizerunek marketingu w Polsce. Pod redakcją Romana Niestroja. Wydawnictwo Uniwersytetu Ekonomicznego w Krakowie. Kraków 2009, s.8.

${ }^{3}$ Szczegółowa informacja na temat struktury próby badawczej jest przedstawiona w: Wizerunek marketingu w Polsce. Pod redakcją Romana Niestroja. Wydawnictwo Uniwersytetu Ekonomicznego w Krakowie. Kraków 2009, s. 10-17. 


\begin{tabular}{|l|c|c|c|c|c|c|}
\hline $\begin{array}{l}\text { Marketing to dziedzina } \\
\text { wiedzy oparta na solidnych } \\
\text { naukowych podstawach }\end{array}$ & 13,2 & 36,6 & 22,6 & 15,7 & 4,2 & 7,8 \\
\hline $\begin{array}{l}\text { Tak naprawdę nie wiadomo, } \\
\text { o co chodzi w tym całym } \\
\text { marketingu }\end{array}$ & 5,9 & 5,7 & 17,5 & 19,8 & 37,6 & 13,6 \\
\hline
\end{tabular}

Źródło: Wizerunek marketingu w Polsce. Pod redakcją Romana Niestroja. Wydawnictwo Uniwersytetu Ekonomicznego w Krakowie. Kraków 2009, s. 18. n= 1909 respondentów.

Gdyby zsumować wyniki w pozycjach ,zdecydowanie tak” i ,raczej tak” to największa zgoda respondentów dotyczyła poglądów wskazujących, że marketing jest związany z różnymi technikami zwiększenia sprzedaży (łącznie $88,9 \%$ respondentów) oraz że jest to koncepcja nieodzowna w biznesie (łącznie 82,2\%). Relatywnie wysoka zgoda respondentów pojawiła się w odniesieniu do opinii, że marketing jest sztuką manipulowania klientem (72,3\%). Dość wysoki odsetek respondentów (59,6\%) uważał, że marketing skutkuje większymi możliwościami wyboru dla klientów, a tylko 23,5\% respondentów zgadzało się ze stwierdzeniem, że marketing to coś, co niepotrzebnie podnosi ceny produktów. Ogólnie rzecz biorąc, badania przeprowadzone w 18 roku transformacji ustrojowej wskazywały na stosunkowo pozytywny wizerunek marketingu jako koncepcji działania przedsiębiorstw na rynku. Zaobserwowano także generalny brak zgody na stwierdzenie ,Tak naprawdę nie wiadomo, o co chodzi w tym całym marketingu".

Od cytowanych badań minęło blisko 8 lat. W tym czasie zmieniła się polska rzeczywistość, ale także kolejne roczniki studentów podjęły studia. Warto zadać sobie pytanie, czy coś w dotychczasowych opiniach już zmieniło się; jeśli tak to w którym kierunku poszły zmiany. Aby odpowiedzieć na te pytania, w 2014 roku przeprowadzono w Akademii Leona Koźmińskiego badania na próbie 203 studentów - słuchaczy wykładów z „Podstaw marketingu” na studiach stacjonarnych oraz „Marketingu” na studiach niestacjonarnych (w obu przypadkach na I roku studiów - semestr II). Badania zostały przeprowadzone na samym początku semestru, a więc opinie studentów bazowały na ich dotychczasowej wiedzy o marketingu i nie były w żaden sposób modyfikowane treścią wykładów.

Podstawą badania był 37 pytaniowy kwestionariusz. Pytania nr 25-34 zawierały 10 stwierdzeń dotyczących marketingu, a pochodzących z kwestionariusza badań przeprowadzonych przez zespól prof. Romana Niestroja. Pytania 35-37 odnosiły się do trzech cech charakteryzujących respondentów - płci, miejsca zamieszkania oraz prowadzenia przez respondenta lub jego rodziców własnej działalności gospodarczej. Natomiast pierwsza część kwestionariusza bazowała na narzędziu (skali) do badania stopnia zaufania konsumentów do marketingu („Index of Consumer Sentiment Toward Marketing").

Indeks ten został skonstruowany przez Johna F. Gaski i Michaela J. Etzela ${ }^{4}$ i wzorował się na narzędziu Survey Research Center Uniwersytetu Michigan powszechnie znanym jako „Index of Consumer Sentiment”. Skala dotycząca zaufania do marketingu po modyfikacjach jest skalą składającą się z 20 stwierdzeń dotyczących czterech

\footnotetext{
${ }^{4}$ Gaski J.F, Etzel M.J., The Index of Consumer Sentiment Toward Marketing. Journal of Marketing, July 1986, 71-81.
} 
głównych komponentów marketingowych, a więc produktu, ceny, dystrybucji i promocji. Każde stwierdzenie jest oceniane przez respondenta na 5-cio stopniowej skali Likerta (całkowicie się zgadzam, zgadzam się, ani zgadzam się, ani nie zgadzam się, nie zgadzam się, całkowicie się nie zgadzam). Dodatkowo skala zawiera ocenę ważności każdego z komponentów marketingowych także na 5-cio stopniowej skali (bardzo ważna, ważna, średnio ważna, niezbyt ważna, nieważna).

W kwestionariuszu badań prowadzonych w Akademii Leona Koźmińskiego, pozycje od 1 do 20 zawierały stwierdzenia dotyczące poszczególnych komponentów marketingu, a stopień zgody na dane stwierdzenie odzwierciedlało pięć opinii na skali Likerta (punkty od 1 do 5 były przyznawane adekwatnie do sformułowania stwierdzenia, które $\mathrm{w}$ pewnej części miały korelację dodatnią, a w pewnej części ujemną $\mathrm{z}$ wartością indeksu). Pozycje od 21 do 24 zawierały ocenę ważności każdego z komponentów marketingowych dla respondenta (także na skali 5-cio stopniowej, a więc odpowiednie punkty stanowiły rangi dla ważenia opinii zawartych w pozycjach 1-20). Dwadzieścia opinii dotyczących różnych działań marketingowych (ocenianych od 1 do 5) zważonych znaczeniem dla respondenta danego komponentu marketin-gowego (także ocenianych od 1 do 5) mogło dać końcową wartość indeksu na skali od 100 do 500.

\section{Wyniki badań}

W badaniach przeprowadzonych na dwóch grupach studenckich (studia stacjonarne i studia niestacjonarne) wzięło udział 203 respondentów. W procesie stratyfikacji wzięto pod uwagę trzy kryteria: płeć, miejsce zamieszkania (wyodrębniając grupę respondentów z Warszawy, grupę zamieszkującą w odległości mniejszej niż 50 km od Warszawy i grupę mieszkającą w odległości większej niż 50 kilometrów) oraz prowadzenie lub nie przez respondenta lub jego rodziców działalności gospodarczej. Strukturę próby do badań ukazuje tabela $\mathrm{nr} 2$.

Tabela 2. Struktura próby do badań w Akademii Leona Koźmińskiego.

\begin{tabular}{|l|l|c|}
\hline \multicolumn{1}{|c|}{ Kryterium } & \multicolumn{1}{|c|}{ Kategoria } & Udział w próbie \\
\hline \multirow{2}{*}{ Płeć } & Mężczyzna & $46,8 \%$ \\
\cline { 2 - 3 } & Kobieta & $53,2 \%$ \\
\hline \multirow{3}{*}{ Miejsce zamieszkania } & Warszawa & $13,9 \%$ \\
\cline { 2 - 3 } & $<50 \mathrm{~km} \mathrm{od}$ Warszawy & $56,2 \%$ \\
\cline { 2 - 3 } & $>50 \mathrm{~km} \mathrm{od} \mathrm{Warszawy}$ & $29,9 \%$ \\
\hline \multirow{2}{*}{$\begin{array}{l}\text { Działalność gospodarcza } \\
\text { rodziców lub respondenta }\end{array}$} & Tak & $72,0 \%$ \\
\cline { 2 - 3 } & Nie & $28,0 \%$ \\
\hline
\end{tabular}

Źródło: badania własne. $\mathrm{N}=203$ respondentów.

Przyglądając się strukturze próby, warto zwrócić uwagę na stosunkowo duży udział (72\%) osób deklarujących prowadzenie własnej działalności gospodarczej lub pochodzenie $\mathrm{z}$ rodziny przedsiębiorców. Opinie wyrażone $\mathrm{w}$ badaniach przeprowadzonych w Akademii Leona Koźmińskiego dotyczące poglądów i obiegowych stwierdzeń na temat marketingu przedstawia tabela $\mathrm{nr} 3$. 
Tabela 3. Opinie studentów na temat marketingu w badaniach ALK (2014).

\begin{tabular}{|c|c|c|c|c|c|c|c|c|}
\hline $\begin{array}{l}\text { Opinie na temat } \\
\text { marketingu }\end{array}$ & $\begin{array}{l}\text { Zdecy- } \\
\text { dowa- } \\
\text { nie tak }\end{array}$ & $\begin{array}{l}\text { Raczej } \\
\text { tak }\end{array}$ & $\begin{array}{l}\text { Ani } \\
\text { tak, } \\
\text { ani nie }\end{array}$ & $\begin{array}{l}\text { Raczej } \\
\text { nie }\end{array}$ & $\begin{array}{l}\text { Zdecy- } \\
\text { dowa- } \\
\text { nie nie }\end{array}$ & $\begin{array}{l}\text { Trudno } \\
\text { powie- } \\
\text { dzieć }\end{array}$ & $\begin{array}{l}\text { Śred- } \\
\text { nia }\end{array}$ & $\begin{array}{l}\text { Odchy- } \\
\text { lenie } \\
\text { stan- } \\
\text { dardowe }\end{array}$ \\
\hline $\begin{array}{l}\text { Marketing to tak } \\
\text { naprawdę to } \\
\text { samo, co reklama } \\
\text { i promocja }\end{array}$ & 5,8 & 47,8 & 21,9 & 16,9 & 7,0 & 1,0 & 2,75 & 0,09 \\
\hline $\begin{array}{l}\text { Marketing to } \\
\text { sztuka } \\
\text { manipulowania } \\
\text { klientem }\end{array}$ & 14,9 & 50,2 & 22,9 & 9,5 & 2,0 & 0,5 & 2,35 & 0,95 \\
\hline $\begin{array}{l}\text { Marketing to coś } \\
\text { nieod-zownego w } \\
\text { biznesie ( } 2)\end{array}$ & 50,2 & 27,4 & 15,4 & 2,0 & 2,5 & 2,5 & 1,87 & 0,16 \\
\hline $\begin{array}{l}\text { Marketing to } \\
\text { interesu-jąca } \\
\text { dziedzina dla } \\
\text { kariery } \\
\text { zawodowej (3) }\end{array}$ & 34,3 & 35,8 & 14,9 & 9,5 & 3,0 & 2,5 & 2,18 & 0,23 \\
\hline $\begin{array}{l}\text { Marketing to coś, } \\
\text { co niepotrzebnie } \\
\text { podnosi ceny } \\
\text { produktów (2) }\end{array}$ & 5,5 & 11,9 & 26,9 & 33,3 & 19,9 & 2,5 & 3,58 & 0,17 \\
\hline $\begin{array}{l}\text { Marketing to } \\
\text { różne techniki } \\
\text { zwiększania } \\
\text { sprzedaży (1) }\end{array}$ & 34,8 & 52,7 & 5,5 & 3,5 & 2,0 & 1,5 & 1,90 & 0,98 \\
\hline $\begin{array}{l}\text { Marketing to coś, } \\
\text { co skutkuje } \\
\text { większymi } \\
\text { możliwościami } \\
\text { wyboru dla } \\
\text { klientów }\end{array}$ & 12,9 & 34,3 & 31,3 & 10,4 & 5,0 & 6,0 & 2,78 & 0,29 \\
\hline $\begin{array}{l}\text { Marketing to } \\
\text { filozofia działania } \\
\text { firm uwzglę- } \\
\text { dniająca przede } \\
\text { wszys-tkim } \\
\text { potrzeby klientów }\end{array}$ & 14,4 & 32,8 & 25,4 & 17,9 & 6,0 & 3,5 & 2,79 & 0,26 \\
\hline $\begin{array}{l}\text { Marketing to } \\
\text { dziedzina wiedzy } \\
\text { oparta na solid- } \\
\text { nych naukowych } \\
\text { podstawach }\end{array}$ & 10,4 & 36,8 & 28,4 & 19,9 & 1,5 & 3,0 & 2,74 & 0,12 \\
\hline $\begin{array}{l}\text { Tak naprawdę nie } \\
\text { wia-domo,o co } \\
\text { chodzi } w \text { tym } \\
\text { calym marketingu } \\
\text { (1) }\end{array}$ & 2,5 & 4,5 & 18,4 & 27,4 & 37,8 & 9,5 & 4,21 & 0,14 \\
\hline
\end{tabular}

Źródło: badania własne. $\mathrm{N}=203$ respondentów.

W tabeli zaznaczono thustym drukiem trzy opinie (oraz wskazano ich kolejność), które uzyskały największą akceptację respondentów (suma opinii 
zdecydowanie tak i raczej tak). Na pierwszym miejscu znalazło się stwierdzenie, że „marketing to różne techniki zwiększania sprzedaży” (97,5\%), „koncepcja niezbędna w biznesie” (77,6\%) i wreszcie ,interesująca dziedzina dla kariery zawodowej” (70,1\%). Z kolei kursywą zaznaczono te opinie, z którymi w największym stopni respondenci nie zgodzili się. Na pierwszym miejscu znalazło się stwierdzenie, że „tak naprawdę nie wiadomo o co chodzi w tym całym marketingu" $(65,2 \%$ wskazań zdecydowanie nie i raczej nie) oraz „marketing to coś co niepotrzebnie podnosi ceny produktów” $(53,2 \%)$. Porównanie wyników z badań w roku 2007 i 2014 przedstawia tabela nr 4. Pokazuje ona równocześnie różnice (przyrosty lub spadki) w odsetku respondentów wyrażających daną opinię.

Tabela 4. Porównanie wyników badań z 2007 i 2014 roku dotyczących opinii na temat marketingu.

\begin{tabular}{|l|c|c|c|}
\hline \multirow{2}{*}{ Opinie na temat marketingu } & \multicolumn{2}{|c|}{ Zdecydowanie tak i raczej tak } & \multirow{2}{*}{ Różnica } \\
\cline { 2 - 3 } & $\begin{array}{c}\text { Badania zespołu } \\
\text { R. Niestroja (2007) }\end{array}$ & $\begin{array}{c}\text { Badania } \\
\text { ALK (2014) }\end{array}$ & \multirow{2}{*}{$+12,6$} \\
\hline $\begin{array}{l}\text { Marketing to tak naprawdę to samo, co reklama } \\
\text { i promocja }\end{array}$ & 41,0 & 53,6 & $-7,2$ \\
\hline Marketing to sztuka manipulowania klientem & 72,3 & 65,1 & $-4,6$ \\
\hline Marketing to có́ nieodzownego w biznesie & 82,2 & 77,6 & $+17,1$ \\
\hline $\begin{array}{l}\text { Marketing to interesująca dziedzina dla kariery } \\
\text { zawodowej }\end{array}$ & 53,0 & 17,4 & $-6,1$ \\
\hline $\begin{array}{l}\text { Marketing to coś, co niepotrzebnie podnosi ceny } \\
\text { produktów }\end{array}$ & 23,5 & 87,5 & $-1,4$ \\
\hline $\begin{array}{l}\text { Marketing to różne techniki zwiększa-nia } \\
\text { sprzedaży }\end{array}$ & 88,9 & 47,2 & $-\mathbf{1 2 , 4}$ \\
\hline $\begin{array}{l}\text { Marketing to coś, co skutkuje większy-mi } \\
\text { możliwościami wyboru dla klientów }\end{array}$ & 59,6 & 47,2 & $-2,0$ \\
\hline $\begin{array}{l}\text { Marketing to filozofia działania firm } \\
\text { uwzględniająca przede wszystkim po-trzeby } \\
\text { klientów }\end{array}$ & 49,2 & 47,2 & $-2,6$ \\
\hline $\begin{array}{l}\text { Marketing to dziedzina wiedzy oparta na } \\
\text { solidnych naukowych podstawach }\end{array}$ & 49,8 & 7,0 & $-4,6$ \\
\hline $\begin{array}{l}\text { Tak naprawdę nie wiadomo, o co chodzi w tym } \\
\text { całym marketingu }\end{array}$ & 11,6 & & \\
\hline
\end{tabular}

Źródło: tabela 1 oraz 3.

Najpoważniejsze różnice pomiędzy opiniami z 2007 roku i 2014 roku (oczywiście przy świadomości nieco innej grupy respondentów) zaobserwowano w trzech przypadkach. O ponad $17 \%$ więcej respondentów uważa, że marketing jest interesującą dziedziną dla kariery zawodowej. Jest to fakt pocieszający po wspomnianym wcześniej narastającym krytycyzmie do marketingu. Ponad $12 \%$ więcej studentów utożsamia marketing z reklamą $\mathrm{i}$ promocją. Świadczy to o wzroście skali i znaczenia różnorodnych działań informacyjnopromocyjnych. Z kolei ponad $12 \%$ mniej respondentów stwierdza, że marketing skutkuje większymi możliwościami wyboru dla klientów. Wynika to prawdopodobnie o zmniejszaniu się stopnia przejrzystości rynku. Warto także dodać, że nieco mniej (o 7,2\%) studentów widzi w marketingu narzędzie manipulowania klientami oraz jako coś, co niepotrzebnie podnosi ceny produktów (mniej o 6,1\%). W przypadku pozostałych stwierdzeń, opinie pozostały na podobnym poziomie.

Interesujące są wyniki odnoszące się do Indeksu Zaufania Konsumentów do Marketingu. Najniższa zaobserwowana wartość indeksu to 126, a największa 360 (przy 
czym im wyższa wartość indeksu tym większe zaufanie). Średnia wyniosła 229,44, a odchylenie standardowe 41,65. Częstość pojawiania się określonych wartości indeksu w odniesieniu do kryteriów płci, miejsca zamieszkania oraz prowadzonej w rodzinie działalności gospodarczej przedstawia tabela nr 5.

Tabela 5. Rozkład wartości Indeksu Zaufania do Marketingu w odniesieniu do wybranych kryteriów stratyfikacji respondentów.

\begin{tabular}{|c|c|c|c|c|c|c|c|c|c|c|}
\hline Indeks & $\mathbf{M}$ & $\mathbf{K}$ & Razem & W-wa & $<\mathbf{5 0}$ & $>50$ & Razem & \begin{tabular}{|l|} 
Dz.gos. \\
\end{tabular} & Bez dzg & Razem \\
\hline poniżej 150 & $1,9 \%$ & $1,0 \%$ & $2,9 \%$ & $0,5 \%$ & $0,6 \%$ & $2,0 \%$ & $3,1 \%$ & $2,0 \%$ & $1,0 \%$ & $3,0 \%$ \\
\hline $151-175$ & $2,5 \%$ & $3,0 \%$ & $5,5 \%$ & $2,0 \%$ & $2,9 \%$ & $1,8 \%$ & $6,7 \%$ & $4,0 \%$ & $1,5 \%$ & $5,5 \%$ \\
\hline $176-200$ & $8,5 \%$ & $7,0 \%$ & $15,5 \%$ & $1,3 \%$ & $11,9 \%$ & $3,2 \%$ & $16,4 \%$ & $11,4 \%$ & $4,0 \%$ & $15,4 \%$ \\
\hline $201-225$ & $10,0 \%$ & $11,8 \%$ & $21,8 \%$ & $3,4 \%$ & $11,4 \%$ & $8,9 \%$ & $23,7 \%$ & $14,8 \%$ & $7,0 \%$ & $21,8 \%$ \\
\hline $226-250$ & $14,9 \%$ & $9,5 \%$ & $24,4 \%$ & $4,0 \%$ & $11,8 \%$ & $9,5 \%$ & $25,3 \%$ & $18,4 \%$ & $6,0 \%$ & $24,4 \%$ \\
\hline $251-275$ & $10,5 \%$ & $6,5 \%$ & $17,0 \%$ & $1,2 \%$ & $7,3 \%$ & $1,3 \%$ & $9,8 \%$ & $12,4 \%$ & $4,5 \%$ & $16,9 \%$ \\
\hline $276-300$ & $3,4 \%$ & $4,0 \%$ & $7,4 \%$ & $1,0 \%$ & $6,8 \%$ & $1,7 \%$ & $9,5 \%$ & $5,0 \%$ & $2,5 \%$ & $7,5 \%$ \\
\hline powyżej 300 & $1,5 \%$ & $4,0 \%$ & $5,5 \%$ & $0,5 \%$ & $3,5 \%$ & $1,5 \%$ & $5,5 \%$ & $4,0 \%$ & $1,5 \%$ & $5,5 \%$ \\
\hline RAZEM & $53,2 \%$ & $46,8 \%$ & $100,0 \%$ & $13,9 \%$ & $56,2 \%$ & $29,9 \%$ & $100,0 \%$ & $72,0 \%$ & $28,0 \%$ & $100,0 \%$ \\
\hline & \multicolumn{3}{|c|}{ Chi $2=7,29 ;$ df $7 p=0,399$} & \multicolumn{4}{|c|}{ Chi $2=26,20 ;$ df $21 \mathrm{p}=0,199$} & \multicolumn{3}{|c|}{ Chi $2=1,03 ;$ df $7 \mathrm{p}=0,994$} \\
\hline
\end{tabular}

Źródło: badania własne.

Wyniki testu $\mathrm{Chi}^{2} \mathrm{w}$ odniesieniu do wartości indeksu zaufania do marketingu oraz odpowiednio płci, miejsca zamieszkania oraz prowadzenia $w$ rodzinie działalności gospodarczej, w każdym przypadku są większe od poziomu istotności $\alpha=0,05$, a więc hipotezy zerowe mówiące o niezależności indeksu od wskazanych kryteriów zostały przyjęte. Interesujący jest rozkład częstości pojawiania się poszczególnych wartości indeksu w odniesieniu do dziewięciu opinii na temat marketingu, w zakresie których respondenci zgodzili się (odpowiedź zdecydowanie tak lub raczej tak). Przedstawia je tabela $\mathrm{nr} 6$.

Tabela 6. Opinie na temat marketingu a wartość Indeksu Zaufania do Marketingu.

\begin{tabular}{|c|c|c|c|c|c|c|c|c|c|}
\hline \multirow[b]{2}{*}{$\begin{array}{c}\text { Odpowiedź: zdecydowanie } \\
\text { tak lub raczej tak }\end{array}$} & & \multicolumn{8}{|c|}{ Wartość indeksu marketingu } \\
\hline & & $\begin{array}{c}\text { pon. } \\
150 \\
\end{array}$ & $\begin{array}{l}151- \\
175 \\
\end{array}$ & $\begin{array}{l}176- \\
200 \\
\end{array}$ & $\begin{array}{l}201- \\
225 \\
\end{array}$ & $\begin{array}{l}226- \\
250 \\
\end{array}$ & $\begin{array}{l}251- \\
275 \\
\end{array}$ & $\begin{array}{l}276- \\
300 \\
\end{array}$ & $\begin{array}{c}\text { pow. } \\
300\end{array}$ \\
\hline & & 1 & 2 & 3 & 4 & 5 & 6 & 7 & 8 \\
\hline $\begin{array}{l}\text { Marketing to tak na-prawdę to } \\
\text { samo, co reklama i promocja }\end{array}$ & $\mathbf{A}$ & 2,8 & 3,7 & 17,6 & 18,7 & 25,2 & 18,7 & 8,4 & 4,7 \\
\hline $\begin{array}{l}\text { Marketing to sztuka } \\
\text { manipulowania klientem }\end{array}$ & B & 2,3 & 5,3 & 17,6 & 25,2 & 21,4 & 16 & 7,6 & 4,6 \\
\hline $\begin{array}{l}\text { Marketing to coś nie- } \\
\text { odzownego w biznesie }\end{array}$ & $\mathbf{C}$ & 3,2 & 4,5 & 14,1 & 21,2 & 25 & 18,6 & 8,3 & 5,1 \\
\hline $\begin{array}{l}\text { Marketing to interesu-jąca } \\
\text { dziedzina dla kariery } \\
\text { zawodowej }\end{array}$ & D & 2,8 & 5,7 & 13,5 & 24,1 & 22,7 & 18,4 & 7,1 & 5,7 \\
\hline $\begin{array}{l}\text { Marketing to coś, co } \\
\text { niepotrzebnie podnosi ceny } \\
\text { produktów }\end{array}$ & $\mathbf{E}$ & 5,7 & 2,9 & 14,3 & 11,4 & 17,1 & 25,7 & 8,6 & 14,3 \\
\hline
\end{tabular}




\begin{tabular}{|l|c|c|c|c|c|c|c|c|c|}
$\begin{array}{l}\text { Marketing to różne techniki } \\
\text { zwiększania sprzedaży }\end{array}$ & $\mathbf{F}$ & $\mathbf{2 , 3}$ & $\mathbf{4 , 5}$ & $\mathbf{1 5 , 9}$ & $\mathbf{2 2 , 2}$ & $\mathbf{2 2 , 7}$ & $\mathbf{1 8 , 6}$ & $\mathbf{8 , 5}$ & $\mathbf{5 , 1}$ \\
\hline $\begin{array}{l}\text { Marketing to coś, co skutkuje } \\
\text { większymi możliwościami } \\
\text { wyboru dla klientów }\end{array}$ & $\mathbf{G}$ & $\mathbf{3 , 2}$ & $\mathbf{6 , 3}$ & $\mathbf{8 , 4}$ & $\mathbf{1 3 , 7}$ & $\mathbf{2 6 , 3}$ & $\mathbf{2 2 , 1}$ & $\mathbf{1 2 , 6}$ & $\mathbf{7 , 4}$ \\
\hline $\begin{array}{l}\text { Marketing to filozofia } \\
\text { działania firm uwzglę-dniająca } \\
\text { przede wszys-tkim potrzeby } \\
\text { klientów }\end{array}$ & $\mathrm{H}$ & $\mathbf{2 , 1}$ & $\mathbf{2 , 1}$ & $\mathbf{1 0 , 5}$ & $\mathbf{1 8 , 9}$ & $\mathbf{2 5 , 3}$ & $\mathbf{2 3 , 2}$ & $\mathbf{9 , 5}$ & $\mathbf{8 , 4}$ \\
\hline $\begin{array}{l}\text { Marketing to dziedzina wiedzy } \\
\text { oparta na solidnych } \\
\text { naukowych podstawach }\end{array}$ & $\mathrm{I}$ & $\mathbf{3 , 2}$ & $\mathbf{3 , 2}$ & $\mathbf{1 5 , 8}$ & $\mathbf{1 8 , 9}$ & $\mathbf{2 8 , 4}$ & $\mathbf{1 5 , 8}$ & $\mathbf{9 , 5}$ & $\mathbf{5 , 3}$ \\
\hline
\end{tabular}

Źródło: badania własne.

W niektórych przypadkach mamy do czynienia $\mathrm{z}$ rozkładem zbliżonym do rozkładu normalnego, w innych mamy do czynienia $\mathrm{z}$ lewo lub prawoskośnością. Zależności w tym zakresie obrazuje rysunek $\mathrm{nr}$ 1, na którym litery $\mathrm{A}, \mathrm{B}, \ldots, \mathrm{H}, \mathrm{I}$ w legendzie odpowiadają rożnym opiniom wskazanym w tabeli nr 6 .

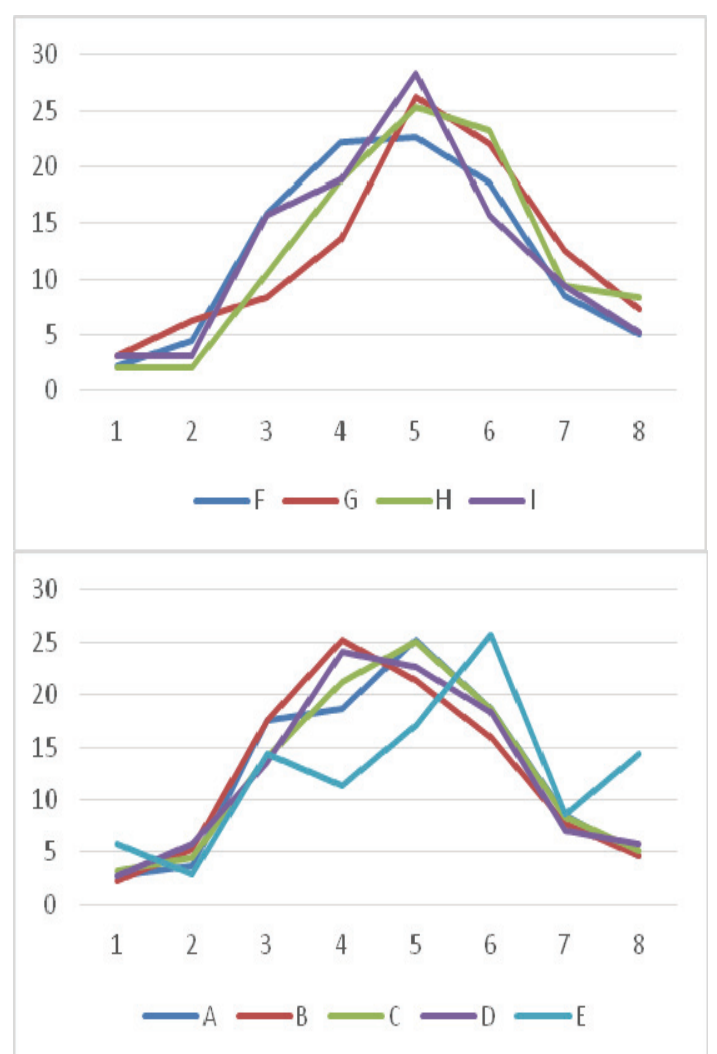

Rysunek 1. Rozkłady częstości wartości Indeksu Zaufania do Marketingu w odniesieniu do poszczególnych opinii na temat marketingu

Źródło: badania własne. 
Rozkład zbliżony do rozkładu normalnego występuje w odniesieniu do stwierdzeń B, C i F, rozkład jest lekko lewoskośny w przypadku stwierdzenia D, lekko prawoskośny przy stwierdzeniu A, natomiast silnie prawoskośny w odniesieniu do stwierdzenia E, G, H, I. Jeśli odnieść się jedynie do silnej prawoskośnosci w rozkładach to oznacza to, że osoby, których zaufanie do marketingu jest większe, także w większym stopniu uważają, że marketing skutkuje większymi możliwościami wyboru dla klienta, że jest to filozofia działania firm uwzględniająca przede wszystkim potrzeby klientów oraz dziedzina oparta na solidnych naukowych podstawach, ale jednocześnie marketing niepotrzebnie podnosi ceny towarów.

\section{Wnioski i podsumowanie}

Przeprowadzone badania pokazały, że obecnie marketing jest w największym stopniu postrzegany jako sposób na zwiększanie wielkości sprzedaży, jako koncepcja nieodzowna w biznesie oraz jako interesująca dziedzina dla kariery zawodowej. Warto przy tym podkreślić, że największe przyrosty w odsetku respondentów zgadzających się $\mathrm{z}$ danym stwierdzeniem wystapiły $\mathrm{w}$ przypadku uznania marketingu jako interesującej dziedziny kariery zawodowej oraz upatrywania w marketingu działań reklamowych i promocyjnych. $\mathrm{Z}$ kolei największy spadek zgody respondentów zanotowano w odniesieniu do poglądu, iż marketing skutkuje większymi możliwościami wyboru dla klientów. Co można było przewidzieć, wzrost pozytywnych opinii na temat marketingu rośnie wraz ze wzrostem wartości Indeksu Zaufania do Marketingu. Jednak nieco zastanawiające jest, że ci którzy w dużym stopniu ufają marketingowi, uważają, że niepotrzebnie przyczynia się on do podnoszenia cen towarów.

Jeśli wziąć pod uwagę fakt, że badania w roku 2014 były prowadzone na grupie, których poziom edukacji marketingowej można uznać za niższy w stosunku do grupy badanej w 2007 roku, to oznacza to, że różne formy edukacji ekonomicznej (np. w środkach masowego przekazu) oraz obserwowane przez respondentów przez lata działania praktyczne zmieniają powoli wizerunek marketingu na bardziej pozytywny.

\section{Literatura}

Bearden W.O., Netemeyer R.G., Haws K.L., Handbook of Marketing Scales. Sage, Los Angeles 2001.

Garbarski L., Pożądane, rzeczywiste i niechciane oblicza marketingu. W: Marketing aktualne problemy i kierunki ewolucji. Pod redakcją M. Gębarowskiego, L. Witek, B. Zatwarnickiej-Madury. Oficyna Wydawnicza Politechniki Rzeszowskiej. Rzeszów 2012, s. 91-99.

Gaski J.F, Etzel M.J., The Index of Consumer Sentiment Toward Marketing. „Journal of Marketing", July 1986, 71-81.

Wizerunek Marketingu w Polsce. Pod redakcją Romana Niestroja. Wydawnictwo Uniwersytetu Ekonomicznego w Krakowie. Kraków 2009.

\section{Summary}

Academic education in marketing and economic education of society have influence on image of marketing in Poland. The article presents an comparison of researches provided at 2007 and 2014 on opinion about marketing. Additionally, analysis of Index of Marketing Sentiment is included. 
The scope and directions of changes in "marketing awareness" trends is presented. Generally, after the period of significant criticism towards marketing concept, the process of positive change in opinion on marketing could be observed.

Key words: marketing image, economic education in Poland

Informacja o Autorze:

Prof. dr hab. Lechosław Garbarski,

Katedra Marketingu

Akademia Leona Koźmińskiego, 03-301 Warszawa, ul. Jagiellońska 57/59

lech@kozminski.edu.pl 